\title{
World Stroke Day
}

\author{
Markku Kaste \\ Department of Neurology, Helsinki University Central Hospital, University of Helsinki, Helsinki, Finland
}

The World Stroke Day, WSD, is celebrated annually on October 29th. The aim of it is to encourage each of us to join the global fight against stroke. Every other second an adult or a child, a man or a woman, old or young, suffers a stroke. Furthermore, every sixth second someone dies because of stroke. If a stroke victim survives, he/she is often severely disabled for the rest of his/her life. Stroke causes a major loss of quality adjusted life years, and does it most often in the developing countries. Furthermore, $85 \%$ of strokes occur for persons with low or moderate risk factors - it can be you or me. What can we do to prevent it? Back in the early 1970s Finland held the unquestionable world record of having the highest incidence of stroke in men and the second highest in women according to the WHO's MONICA project. Then the NorthKarelia project was launched and in the 1980s the incidence and mortality started to decline in Finland - and they keep on declining.

Most strokes occur in developing countries with limited financial resources. How can they afford to fight against stroke? The annual WSD competition has revealed that it is possible, and furthermore, it is possible to do it effectively. Based on the competition, it even looks like that it can be done better in the developing countries than in many wealthy countries. Over sixty countries and regions took part in the WSD competition of 2009. The

This article has been co-published in the International Journal of Stroke and Stroke.

\begin{tabular}{ll}
\hline KARGER & $\begin{array}{l}\text { (c) 2011 S. Karger AG, Basel, John Wiley \& Sons, Inc., } \\
\text { and American Heart Association, Inc. }\end{array}$ \\
$\begin{array}{l}\text { Fax +4161306 1234 } \\
\begin{array}{l}\text { E-Mail karger@karger.ch } \\
\text { www.karger.com }\end{array}\end{array}$ & $\begin{array}{l}\text { Accessible online at: } \\
\text { www.karger.com/ced }\end{array}$
\end{tabular}

winners were selected based on innovation, message and reach of the activities executed. The same criteria were used when ranking the 2010 WSD competition, in which about the same amount of countries and regions took part. The winners of WSD 2010 are Guntur - India, Hungary and Nigeria and the three Honorable Mentions go to Bengal - India, Russia, and Kerala - India.

In both competitions the campaigners worked hard at grass root level. They organized information campaigns in newspapers, radios and TVs, and delivered lectures for professionals and lay people about how to prevent stroke and how to treat it. They had successfully invited ministers to join these activities and founded stroke societies and stroke support organizations. It is amazing how innovative, energetic and active these foot soldiers in the war against stroke had been. We know for a fact that such activities were executed also in many other regions, which did not take part in the WSD competitions. Obviously they thought that what matters the most is what you do locally whether or not people around the world know about it. The best thing about the two WSD competitions is the fact that most of the winners came from developing countries. Their activities verify that hard work to reduce the burden of stroke can be done anywhere in the world.

The success of the WSD competitions has shown that it is possible to fight against stroke worldwide. This should encourage us all to follow the examples of the winners of the WSD competitions. If you have not yet done it, now is the time to join the forces in the fight against stroke. Just look in the mirror and you will see the one who should take this challenge.
Markku Kaste, MD, PhD, FAHA, FESO

Department of Neurology, Helsinki University Central Hospital

University of Helsinki, PO Box 340, Haartmaninkatu 4

FI-00029 HUS, Helsinki (Finland)

Tel. +3589471 72220, E-Mail markku.kaste@hus.fi 